Eurostudia

\title{
The Soviet Secularization Project in Central Asia: Accommodation and Institutional Legacies
}

\section{Hélène Thibault}

Volume 10, numéro 1, 2015

From Today's Observation Post: Collaboration and Resistance under Communism

Vues du poste d'observation du présent : collaboration et résistance sous le communisme

Kollaboration und Widerstand im Kommunismus - Betrachtungen aus heutiger Sicht

URI : https://id.erudit.org/iderudit/1032440ar

DOI : https://doi.org/10.7202/1032440ar

Aller au sommaire du numéro

Éditeur(s)

Le Centre canadien d'études allemandes et européennes

ISSN

1718-8946 (numérique)

Découvrir la revue

Citer cet article

Thibault, H. (2015). The Soviet Secularization Project in Central Asia: Accommodation and Institutional Legacies. Eurostudia, 10(1), 11-31. https://doi.org/10.7202/1032440ar
Résumé de l'article

This article investigates the effects of the Soviet social engineering project and forced secularization in Central Asia. Emphasis is placed on the ideological foundations of Marxism-Leninism, its stance on atheism, its holistic character, and its ideological exclusivity. The article details the measures taken by authorities to eradicate religious beliefs during the seventy years of Soviet rule. Taking the case of Tajikistan, it highlights the remaining influence of Soviet policies on state-religion relations by reviewing the functions and responsibilities of current regulatory institutions as well as laws and official discourses framing religious practices.
Tous droits réservés $@$ Le Centre canadien d'études allemandes et européennes, 2015
Ce document est protégé par la loi sur le droit d'auteur. L'utilisation des services d’Érudit (y compris la reproduction) est assujettie à sa politique d'utilisation que vous pouvez consulter en ligne.

https://apropos.erudit.org/fr/usagers/politique-dutilisation/ 


\title{
Hélène Thibault
}

Chaire de recherche en étude du pluralisme religieux

Cérium, Université de Montréal

\begin{abstract}
:
This article investigates the effects of the Soviet social engineering project and forced secularization in Central Asia. Emphasis is placed on the ideological foundations of Marxism-Leninism, its stance on atheism, its holistic character, and its ideological exclusivity. The article details the measures taken by authorities to eradicate religious beliefs during the seventy years of Soviet rule. Taking the case of Tajikistan, it highlights the remaining influence of Soviet policies on state-religion relations by reviewing the functions and responsibilities of current regulatory institutions as well as laws and official discourses framing religious practices.
\end{abstract}

\section{Introduction}

Following the Bolshevik revolution in 1917, the modernization process in the Soviet Union was imposed with the help of extensive financial and material resources as well as propaganda. Though their message was emancipating, the Soviets used highly repressive methods to impose their authority, including arrests as well as the physical elimination of saboteurs and opponents. Seventy years of Soviet rule have profoundly impacted former Soviet societies and the extent of the socio-economic transformation is especially striking in Central Asia, when compared to its southern neighbour, Afghanistan.

Almost certainly, such repressive political order will have left people bitter and unregretful. Yet, Russian-American scholar Alexei Yurchak denounces the common popular and academic assumption that the Soviet period only represents a dreadful historical period. He is careful to avoid using antagonistic positions between resistance and collaboration and instead proposes to analyse social behaviour as entailing "interesting and creative acts 
of rendering communist ideology meaningful within the broader frame-work of human values" (Yurchak 2003, 482). Following this line of thought, this article investigates the effects of the forced secularization and the Soviet social engineering project in Central Asia. It suggests interpreting the reality of socialism in terms of accommodation of values rather than passive resignation (Froese 2008) or resistance (Poliakov 1992). It focuses on socialization and education to argue that even though secularization was not entirely successful, in the sense that Soviets failed to eradicate religion completely, the attempt to secularize its population deeply informed the understanding of the place of religion in society for generations of Soviet citizens. I will first present an overview of the Soviet ideology by emphasizing its holistic character and how it informed the implementation of secular policies. I will then address the debate on the success or failure of the secularization process in Central Asia. In the third part, I will make use of the Tajik case to highlight the remaining influence of Soviet policies on state-religion relations in Tajikistan. I will outline the similarities between Soviet and post-Soviet institutions and discourses by illustrating the authorities' attempt to subordinate religious practices and define an Islam consistent with national ideals.

\section{Secularizing Central Asia}

The Soviet ideology, with its absolute values and objectives, aimed at the creation of a new society and a new man. Soviet thinkers fully acknowledged the holistic character of the ideology promoted by the Communist Party. This was not perceived as something negative, quite the contrary. A noteworthy statement of this position is Lenin's famous quote: “The Marxian doctrine is omnipotent because it is true. It is complete and harmonious, and provides men with an integral world conception which is irreconcilable with any form of superstition, reaction, or defense of bourgeois oppression" (Lenin 1913).

Because Marxism-Leninism was a philosophy "that has implications for just about every aspect of society, from the family to international relations" (Marsh 2011,18), some authors conceptualise it as a religion in itself with its own ideology, worldview, moral codes, and rituals (Agadjanian 2011; Codevilla 1971; Marsh 2011). Codevilla suggests that: "for its messianic and prophetic attitude, it [Marxist-Leninism] takes on a religious hue" (Codevilla 1971, 26). Yet, as Keller puts it, "If we consider for a moment the role of Marxism-Leninism as a quasi-religion, Stalin and his supporters, in fact, 
exhibited very little faith in their doctrine" (Keller 2001, 250). Despite the civic rituals, the cult, and the myths Communists have built over time, I do not regard Materialistic-Atheism as a religion. Gellner (1991) is right when he underlines the impossibility of associating Soviet Marxism with religion. Even though he acknowledges the similarities between Marxism and religions, Gellner argues that: "at the doctrinal and intellectual level the proud boast of Marxism was that it had exiled the supernatural from social life" (1991, 1). Following Pospielovsky, I argue that Sovietism is a worldview which entails: "1- A certain vision of the relationship between man and nature 2- A concrete understanding of the relationship between man and society or groups of men and society 3- A certain understanding of the meaning of life, of human nature and its destination" (Pospielovsky 1987, 21).

Husband argues that atheism was not a significant part of the Bolshevik's prerevolutionary messages nor did it influence their victory. Instead, the revolutionaries elaborated ad hoc the complex cultural strategies that would transform the face of the empire (Husband 2000, 35). Much confusion marked the first years of Soviet rule in the newly created Turkestan Republic. Politics is often a process of trial and error, and so were the early Soviet policies by which leaders, in an uncertain administrative, political and social environment, introduced rapid changes while trying to avoid creating too much unrest. Various decrees and laws were adopted to further codify the practice of religion, especially the status of religious organizations rather than individuals, who were being addressed through other means, namely, atheist propaganda and social pressure. Constitutional amendments, laws and decrees were frequently subject to change and reflected their respective sociopolitical times. Before the 1930s, the pressure on religious communities was constant but diffuse compared to the more radical actions against religious figures and believers that would be taken by the Soviet authorities later during the period known as the "Great Stalinist Purges," between 1930 and 1939. Overall repression was brutal and some reports estimate that between 1917 and 1939, 140,000 Muslim clergy were arrested, killed, or exiled (Keller 2001, 241).

Although repression was never completely abandoned, in the later years, emphasis was put on propaganda and education. Kenez rightfully points out that the word propaganda carries a negative connotation. Indeed, people usually understand propaganda as a Machiavellian attempt to 
disseminate false information in order to influence or fool people. However, he suggests that, unlike the Nazis, the Soviets were not interested in the techniques or philosophy of mass persuasion; instead, they saw propaganda as part of education campaigns (Kenez 1985, 8). Beyond propaganda efforts, education and literacy campaigns truly became the capital agent of change. Agitatsiya can only give limited results and reach a limited number of individuals, whereas public education can sway a very large and impressionable young audience. Indeed, authorities thought that a high level of social and economic development combined with a materialistic atheistic education would inevitably lead to the transformation of the society, from god-fearing to godless (Skazkin 1968, 479). As Gellner argues (2008), modern education systems serve to inculcate shared understandings and values so that people understand, interact, and cooperate with each other in modern, production-oriented societies. In August 1930, the adoption of a decree on General Compulsory Primary Education at the all-Union level was echoed in similar laws in each Republic, even though implementation proved difficult in the conservative environment of Central Asia (Keller 2001, 209). Soviet atheism specialists insisted on the educational aspect of atheist propaganda that would lead to the achievement of socialist goals. Kurochkin, a Soviet ideologue, explains how the scientific and materialist atheistic Weltanschauung must be reproduced and expanded in every new generation of socialist society (Kurochkin 1983, 144), because according to him the danger of religious revival was never far away. The following instruction of one Soviet ideologue evokes the need for, and the expected results of, atheist propaganda:

It is necessary to conduct systematic extensive scientific atheist propaganda, to patiently explain the fallacy of religious beliefs that have arisen in the past due to the people's domination/pressure under elemental forces of nature and social oppression and their ignorance of the true causes behind natural and social phenomena. It should build on the achievements of modern science, which fully reveals the picture of the world, increases the power of man over nature, and leaves no room for the fantastic religion's fiction on super-natural forces (Rosenbaum 1985, 29).

The liberation of women from the patriarchal oppression imposed by feudal and capitalist societies was also an important aspect of the socialist project, and the promotion of women's rights was an integral part of the political platform of the Bolsheviks from the very beginning. In Marxist

In Russian, agitatsiya refers to public campaigning or action meant at creating awareness on a specific topic. 
rhetoric, Central Asian women were identified as a "surrogate proletariat" because of their subordinate position within the patriarchal structure of both the society and the family. Therefore, women had to be liberated (Northrop 2004, 12). In Central Asia and in the Muslim regions of Russia, the promotion of women's rights had twin objectives: to ensure the equality of rights for men and women, but perhaps even more importantly, to undermine the Islamic clergy and religious traditions (Northrop 2004).

Due to their own weak organisational capacities, as well as popular discontent and the clergy's social and political importance, at the beginning of the Forties, the Bolsheviks returned to what Keller refers to as "the strategy of Catherine the Great," that is, "control through co-optation." Authorities felt they had no choice but to try to channel religious behaviour by establishing religious standards, trying to make them as compatible as possible with Soviet norms. The creation of religious administrations in the post-war period provided authorities the means to achieve this goal by reaching believers and by trying to influence their religious practices. ${ }^{3}$ Four such administrations appeared throughout the Soviet Union during the war period: the Spiritual Administration for European Russia and Siberia in Ufa, for the Northern Caucasus in Buinaksk (Dagestan), for Transcaucasia in Baku and also the Spiritual Muslim Board of Central Asia (SADUM) (Ro'i 2000, 100). Multiple factors doubtless explain the decision to create religious administrations, ${ }^{\circ}$ but the bottom line is that the regime perceived the clergy and religious communities "as a defeated and controllable enemy" (Keller 2001, 251). The end result was the creation of an official Islam in the USSR that was used to frame religious practices as well as an instrument of foreign policy when dealing with Muslim countries (Fourniau 1994, 118).

This instrumentalisation of religion created space for the official practice of religion as well as religious teaching, which was kept under the close

\footnotetext{
2Massell (1974) was the first to use this term.

'Other faiths had their own religious administrations but, unlike for Muslims, their representation was not territorial. Russian Orthodox, Gregorian Armenian, Evangelist Christian Baptists and Lutherans had representations while Roman Catholics and Jews had no centre (Ro'i 2000, 23).

‘ This directorate was moved to Baku in 1974 (Ro'i 2000, 100).

s The acronym stands for its name in Russian: Srednoe Aziatskoe Dukhovnoe Upravlenie Musul'man. The latter would become primus inter pares (Ro'i 200,53).

- The most common explanation for the creation of these bodies is that they were a reward for Soviet Muslims who participated in the war effort (Haghayegi 1995, 26-27) as well as an attempt to give a democratic image to the authorities (Babajanov 2000b, 81).
} 
supervision of the authorities (Sadur 1989, 439; Babajanov 2000, 82-3). From 1948 to 1991, there were only two functioning medresses in the whole of Central Asia, the Mir-i Arab one, opened in Bukhara in 1946 and the AlBukhari in Tashkent founded in 1956. In 1971, the Institute for Higher Islamic Studies was established in Tashkent (Epkenhans 2010, 317). There were no official medresse apart from the ones in Uzbekistan, so the opportunities to learn the basics of religion legally were nearly nonexistent, since private religious education was forbidden. Yet, many religious figures engaged in the unregistered teaching of students. The existence of these secret religious study cells, or hujra, was an open secret, winked at by the KGB (Brill Olcott 2007, 30).

As much as they would have liked to get rid of competing religious ideologies forever, Soviet authorities had no choice but to acknowledge them as an inevitable and undesirable defect, which must be dealt with. In fact, Soviet literature is filled with conclusions and recommendations about the resilience of religion and suggestions for future adoption of methods to undermine it (Pospielovsky 1987). Soviet institutions of regulation kept manifestations of religion under strict control but there were rituals performed outside sanctioned mosques and sometimes with the complicity of local authorities on state farms for instance.

This is a phenomenon referred to as "parallel Islam." The term is borrowed from Soviet sociologists and was first introduced by Alexander Bennigsen in 1968 (Poujol 2005, 53). It refers to the type of Islam practised during the Soviet period as opposed to the Islam labelled as "official," which was promoted and controlled by the SADUM. Parallel Islam was clandestine but supported by a network of underground organizations, mainly Sufi Brotherhoods (Myer 2001, 181). Ro'i, who helped popularize the term, underlines the importance of parallel Islam by pointing out that the number of official mosques in the Soviet Union comprised only $1 \%$ of the actual total (Ro'i 2000, 288). By way of comparison, in the 1980s, there were officially 200 "central" mosques in Central Asia (Abdulgani 1989, 405), s three of them in Northern Tajikistan (two in Leninabad and one in Proletarsk). Poliakov's

\footnotetext{
An advanced religious school.

s The Tajik designation is Masjidi Jomeh (Friday mosque) and Sobornaya mechet' (Cathedral mosque) in Russian.
} 
ethnographic expedition, however, estimated the number at around 200, a number at least equal to that of pre-Soviet times (Poliakov 1992, 96-97). In 1982, in Tajikistan, no less than 21 underground schools were discovered by the authorities (Ro'i 2000, 358). Numerous testimonies of Central Asians tell of secret performances of religious rites, including Islamic weddings (Nikoh), circumcisions (Hatna) and funerals (Dzhanoza), as well as stories of people praying in caves or among trees, or secretly riding bikes at night to attend religious classes. Such activities placed people at great personal risk, as they could be prosecuted for performing such acts or for attending unsanctioned services..$^{10}$ Indeed, contrary to Gellner's opinion in 1991 that in the USSR, "faith has now totally disappeared" (1991, 1), religion did not vanish. Despite the coercion of religious leaders, severe repression of believers and 70 years of persistent atheist propaganda, religious beliefs and rituals lived on, albeit altered.

\section{The Soviet Modernization Project: Views on Success and Failure}

Many authors have underlined the failure of the Soviet's transformative attempt. For instance, Myer's survey of the literature shows that a majority of scholars endorse the idea of a failed transformation. In particular, they emphasize Central Asian peoples' distinctiveness, manifested through the persistence of local languages (as an important cultural marker), the survival of cultural traditions (respect for elders, gender division, large families), and the resilience of religion (Fierman 1991). Poliakov suggested that, in many respects, the structure of the traditional society has been preserved because Soviet authorities simply superimposed their authority on existing structures, notably, production units in Central Asia (Poliakov 1992, 17). The issue of religion is what authors see as the breaking point dividing Muslims from Russians and the main reason why assimilation did not work (Myer 2001, 169173). Rywkin (1982) has most strongly stated the failure of Soviet policies in Central Asia and “USSR's Muslim problem."

\footnotetext{
- Sergei Petrovich Poliakov is a Russian ethnographer who published an influential book in the USSR in 1989 about everyday Islam in Central Asia; his research focuses mainly on Northern Tajikistan. His main findings point to the failure of Soviet policies and the continuing influence of the clergy and traditional ideas among the population. Poliakov's work was later strongly criticized for its prescriptive ethnography, which represented a typical Soviet view on religious life (Deweese 2002, 315).

${ }^{10}$ In Turkmenistan, circumcision was forbidden until 1989 (Poliakov 1992, 56).

"In the 1970s and 1980s, authors like Rywkin (1982) and Carrère d'Encausse (1978) predicted that the USSR's Muslim republics would be the ones precipitating the fall of the Union because of their
} 
DeWeese refers to this discussion as a "fruitless debate" and argues that, when comparing Central Asia to the rest of the Islamic world, it is easy to conclude that the Soviets definitely "succeeded all too well" (DeWeese 2002, 302). Therefore, the question should not be whether or not the Soviets managed to transform the societies of the former USSR but how? On that matter, Adams, in her investigation of the cultural revival in post-Soviet Uzbekistan, mentions: "The story that I find myself telling is one not of an Uzbek cultural renaissance blossoming in the wake of independence but, rather, of the successful institutionalization of a Soviet cultural schema that continue to define Uzbek culture and national identity" (Adams 1999, 336). Dealing more specifically with the issue of religion, Wanner suggested that secularization does not lead to the eradication of religion but rather that secularization processes draw on "particular views of how religion should relate to politics, governance, and public affairs and lead to religious change" (Wanner 2011, 219). The focus here should not be on the extent to which atheistic ideas conquered the hearts and minds of individuals but rather on the way it affected people's understanding of the role of religion in society.

\section{Accommodation in Context}

Yurchak has adroitly touched upon the issue of accommodation with his study of the appropriation and reinterpretation of Soviet values and discourses by the late Soviet generation. He proposed to study Soviet hegemony not only in relation to its hegemonic discourse but its "meaning inscribed in ideological performance and representation" (Yurchak 2003, 480-1). He advised scholars to "question how Soviet people in fact interpreted the lived ideology and reality of socialism" (Yurchak 2003, 485).

The concept of accommodation supposes that imposed practices and discourses are not only contested or passively accepted but can be negotiated and contribute to the making and remaking of personal and socio-political identities. Thinking in terms of accommodation instead of resistance or resignation allows us to give agency to individuals in a broader sense than by referring to the concept of resistance. This is the case because resistance usually implies a concerted and motivated defiance of authorities. In James

demographic weight and the failure of transforming Muslim people into Homo Sovieticus, to use a term coined by Carrère d'Encausse. As history showed, it was rather nationalist mobilizations in the Baltic republics that destabilized the country. 
Scott's examination of peasant resistance in Malaysia, he described "everyday form of resistance," actions that required little or no coordination and which were conducted with "ordinary weapons of relatively powerless groups such as foot dragging, dissimulation, false compliance, sabotage, etc." As a result of these mostly non-violent actions, peasants engaged in low-intensity conflicts with the authorities (Scott, 1985, 29). And yet, while Scott's studies gave a new understanding to the concept of resistance, it did not allow for the consideration of different responses to authoritative change because people don't always resist; many comply, many defy, but many more accommodate. As summarized by Husband: "In a larger context, far more citizens everywhere practice accommodation than ever take up activism" (Husband 2000, 150).

Husband looked at secularization campaigns in Russia between 1917 and 1932 and studied the way people tried to resist and to accommodate the imposition of a secular lifestyle. In trying to break the image of passive submission conferred to populations, Husband mentions that it created "circumstances in which individuals and groups not only had the opportunity to reevaluate their relationship to the sacred, but indeed could not escape doing so" (Husband 2000, 162). Northrop goes in the same direction by focusing on strategies of Central Asians to cope with Soviet colonialist policies (Northrop 2004), in particular the transformation of gender relations in the absence of proletarian classes. Northrop focuses on the discursive and physical battle over the definition of proper forms of everyday life, which involved both the Soviet authorities and Uzbek women and men. In his later book, which covers the whole Stalinist period, he concludes that: "In the local encounter between Soviet power and Central Asia, both sides emerged transformed" (Northrop 2004, 345). Northrop acknowledges that by the late 1960s in Uzbekistan, "the Russians' self-styled European mission appeared, at long last, to have achieved hegemony among Central Asians themselves" (Northrop 2004, 351) and that in contemporary Uzbekistan, the Hujum, the Soviet campaign for unveiling Central Asian Muslim women, is almost universally seen as a positive mark of progress and a landmark of the Uzbek nation's development (Northrop 2001, 115).

Beyond literacy campaigns and the transmission of values via a standardized education, Suny argues that the Soviet authorities and the intelligentsia managed to foster emotional connections "first to the Revolution 
and Civil War, the project of creating a new world, then to Lenin and Stalin as personifications of the Soviet project, later to the victory over fascism" (Suny 2012 , 23). The end result was the creation of a powerful civic culture that connected persons from an extended space. Likewise, Lane suggests that Soviet rituals were effective tools because they often blended with "interpersonal values that bind the individual to his family and his local community" and "rechannel them towards the large and more impersonal political collective" $(1984,215)$.

Indisputably, Central Asia ended up being profoundly transformed by the Soviet social engineering project. But given the resilience of traditional customs and religious habits, there is no doubt that Sovietization was not entirely successful. The Soviet transformative process cannot simply be described as the imposition of foreign atheist modernistic norms and values upon traditional societies. Opposing both the idea of the resignation of Soviet peoples and the exceptionalism of the Soviet experience, Suny argues that: "supposed Russian exceptionalism is to see the ethnic or national as selfgenerated and the socialist and Soviet to be an artificial imposition" (Suny 2012 , 17). The social engineering project should rather be seen as a process of forced negotiation between foreign and local norms in which some local actors retained agency.

\section{Accommodation and Path Dependency}

I will now address the Constitutional aspects, the laws and institutions that frame the practice of religion in today's Tajikistan in light of the Soviet legacy. The objective is to underline how accommodation leads to the reinterpretation of Soviet practices. I do so by highlighting the similarities between Soviet and post-Soviet institutions and discourses and by illustrating the authorities' attempt to subordinate religious practices and define an Islam consistent with national ideals.

Overall, provisions of the Tajik Constitution are rather standard and do not reveal much about state-religion relations. Yet, it testifies of the Soviet heritage since it explicitly mentions the secular character of the state in their Constitution." More importantly, in Tajikistan, the presence of institutions

\footnotetext{
12 Very few national Constitutions have this provision. Those include the five Central Asian countries, Azerbaijan, but also France and Turkey (Fox 2011).
} 
such as the Council of Ulemas and the Committee of Religious Affairs, ${ }^{13}$ heir to the SADUM, the Soviet Tajik Qaziat and the Soviet Committee of Religious Affairs clearly illustrate the institutional continuity with the Soviet period." The Council is more concerned with the spiritual aspects of religious life and training whereas the Commitee is a governmental body enforcing the laws regulating religious practice. Independent on paper, these institutions are not perceived as such and often criticized for following the official party line. Politics in Tajikistan has been characterized by a lack of political plurality since the end of the civil war in 1997. Though genuine opposition parties exist and compete in the elections, the President's People's Democratic Party of Tajikistan always wins a majority of seats in Parliament. Also, due to Constitutional amendments adopted in 1999 and 2003, Emomali Rahmon has managed to remain President since 1994, though he has been acting as the Head of the state since 1991. ${ }^{\text {s }}$

We find in Tajikistan, as well as in the other Central Asian Republics and Russia, a law called Law on Freedom of Conscience and Religious Associations. Like its earlier Soviet version, the law regulates freedom of conscience and freedom of religion, relations between the state and religious communities, as well as their legal status. Over the years, the law became increasingly detailed and restrictive. Originally adopted in December 1994, it was profoundly redrafted by the Tajik Committee of Religious Affairs (CRA) in 2006 and adopted only in 2009. Before and after its adoption, the law was denounced by local and international advocacy organizations as one of the most restrictive law on religion in the region (Corley 2009; OSCE 2006, 2008; Ozod 2009).

Numerous provisions on the regulation of religious practices appear rather intrusive. For instance, the law deals with the number of mosques that can be erected. The same article stipulates that the selection of imams must receive the approval of the responsible state organ, that is, the Committee of Religious Affairs. By law, the CRA has no right to interfere with the selection of imams and local communities are responsible for selecting their own imam

\footnotetext{
${ }^{13}$ In Tajik, Shuroi Ulamo, in Russian Soviet Ulemov.

"Similar institutions are found in all Central Asian republics as well as in Russia.

${ }^{15}$ A new Constitution was adopted in 1994 and amended in 1999 and 2003. The 1999 Constitutional Referendum extended the presidential term from five to seven years while the 2003 amendments extended the number of terms that a Tajik president may hold office, from one to two seven-year periods (Abdullaev 2005). Rahmon was due to leave office in 2006 but was re-elected in the 2006 and 2013 presidential elections.
} 
through negotiation and deliberation. They then send the decision protocol to the CRA's local office which provides the license. However, it appears that the CRA has a say in the choice of imams (Epkenhans 2010, 326), which unambiguously violates the neutrality of the state as well as undermines the independence of religious communities.

Among other controversial provisions, procedures for the registration of mosques and religious associations have been complicated so that founding members must now provide local authorities with 200 signatures in support of their association. It thus limits the possibilities for small communities, especially non-Muslim groups, to set up an organization. This is a restriction that is reminiscent of Soviet practices as authorities considered small groups more suspicious than established religions, because they could not be easily monitored (Bryanov 1986, 54-55). Proselytism per se is allowed since religious communities have the right to inform people about their faith and beliefs; however, according to Article 23(4), they may not do so in state buildings, schools and private homes, which greatly restrict the capacities of communities to reach out to the public. Finally, Article 9(3) states that public officials, public servants, leaders, and members of political parties cannot fund or be employed by religious groups, which creates membership issues for the Islamic Revival Party of Tajikistan (IRPT), the only legal faith-based party in Central Asia. Integrated into the country's power structures in 1997 as a result of the signing of a peace agreement, ${ }^{16}$ the party has since been marginalized to the point that it is now threatened by a full-fledge ban (Asia Plus 2015). ${ }^{17}$

Another controversial law, entitled Law on Parental Responsibility in the Upbringing and Education of Children, adopted in 2011, represents a serious infringement of religious rights. In particular, Article 8, entitled Parental education duties sparked the strongest critique. ${ }^{\text {s }}$ It most contentious provision

\footnotetext{
1s The agreement devised the allocation of 30 per cent of the ministerial positions to the opposition, a provision that was slowly implemented and which remained largely unaccomplished (Kabiri 2002, 55). Yet, in 1999, 5,377 veterans of the United Tajik Opposition joined the Army ranks as well as frontier and regular police services (Khamadov and Olimov 2003, 52).

"In 2000, the Islamic Revival Party of Tajikistan lost the Ministry of Economy, occupied by Davlat Usmon between 1998 and 2000 (Dudoignon 2005, 126). Immediately after the 2006 presidential election, which had been boycotted by the IRPT, Rahmon implemented a drastic reorganization of the administration, following which the IRPT was even more marginalized (RFE/RL 2006).

"The Communist Party of Tajikistan seems to have been the only opposition party in favour of the new legislation. The Communist leadership commented Article 8 in such terms: "We have students who leave aside their studies to hurry to the mosque, the state must necessarily respond to this" (Yudalshev 2011).
} 
forbids parents to let children participate in the affairs of religious associations at the exception of those who are officially enrolled in religious education institutions and at the exception of funerals. At the same time, access to religious education has become more difficult as the number of religious education institutions has not ceased to decrease over the years. In 2003, the Islamic Institute in Dushanbe as well as 21 medresses were responsible for providing religious teachings (ICG 2003, 17). In 2010, there were still ten medresses in the Sughd region but many were closed down in 2011 (Rafiyeva 2011). Finally, in the summer of 2013, the authorities suspended five of the country's six remaining medresses, which were all located in Sughd. The CRA invoked that they failed to provide proper documents for registration (RFE/RL 2013). As such, the Medresse Abu Hanifa in Dushanbe, a joint project between the Tajik and Swiss governments, is now the country's only functioning medresse but its future operation is now jeopardized (Islam News 2015).

On many occasions, President Emomali Rahmon has denounced religious education and its perverse effect on radicalization (BBC Monitoring 2007, Najibullah 2010). Abdudjabbor Rahmonov, the Minister of Education between 2005 and 2013, was especially virulent in his condemnation of parents who send their children to study with mullahs (Asia Plus 2010). Such discourses are pervasive in Tajikistan and carry a negative tone that is reminiscent of Soviet anti-religious propaganda. The authorities' inclination to control religious education exceeds national borders and the movements of Tajik students abroad have severely been curtailed. Concern over foreign education became especially salient after a Presidential speech in August 2010 in which Emomali Rahmon urged parents to "bring their children home." According to him: "Most of them will become extremists and terrorists, because those schools don't only teach religion" (Najibullah 2010). In fact, the Law on Freedom of Conscience stipulates that Tajik citizens may pursue religious studies only after receiving religious education in the Republic of Tajikistan and with the written consent of authorized state bodies on matters of religion and education (Article 8[6]). For that reason, Tajik authorities forced the return of nearly 2,000 Tajiks who were studying in foreign medresses or Islamic Universities in 2010. That summer, the authorities went as far as prevented in

19 Already in 2007, he had blamed "parents who bring their child to a half-educated mullah, and with a stick he tells them to learn the Koran by heart" (BBC Monitoring 2007). 
extremis aspiring students from boarding a plane at the Dushanbe airport prior to its departure to Iran (Najibullah 2010). Families of students were allegedly pressured by security enforcement agencies to urge their offspring to come back (Mirsaidov, Rasul-Zade and Dikaev 2010), after which some of them also had to face prosecution (RFE/RL 2011).

Limited access to religious education certainly contributes to the popularity of foreign Islamic institutions. Also, many religious figures as well as political figures complain that the level of theological knowledge is very poor and that this encourages students to pursue their studies abroad (ICG 2003, 17; Todzhiddinov 2011). Even the Consultative Council of the Muftis of the Commonwealth of Independent States ${ }^{20}$ is of this opinion and suggested that the Council should take measures to raise the level of education of religious leaders (Isazade 2013).

Other measures have been taken to prevent Islamic foreign influence. The government has banned several organizations in the last few years. Among them are well-known groups such as the Hizb ut-Tahrir, al-Qaeda, the Taliban, and the Islamic Movement of Uzbekistan. The last three are known for their terrorist activities; others, such as the Muslim Brotherhood and Hizb ut-Tahrir, hold fundamentalist views but are non-violent political parties (Karagiannis 2006). In the last decade, thousands have been prosecuted and condemned for their involvement in one of these organizations. Sentences tend to be heavy in Tajikistan and convicts received prison terms ranging from five to 30 years (Rafiyeva 2012).

The subordination of religion to political orientations is undeniable and interestingly, authorities do not deny the control exerted over the Council. It is in fact presented as a necessary measure to protect Islam against deviances. On that matter, the words of the President of Tajikistan, Emomali Rahmon are unequivocal:

The state in the framework of the acting legislation has authority to oversight activities of religious organizations in order to protect peace, stability, noble birth and cultural values of the people in the country. The direct obligation of the Islamic Center and the Council of Ulemas of Tajikistan is to consider their sermons and moral admonitions. Therefore, it is the obligation of the concerned state government bodies to consider the

${ }^{20}$ The CIS is a regional organization regrouping nine countries of the former Soviet Union. 
cases when such sermons and moral admonitions contradict to the

Constitution and other acting laws of Tajikistan (Rahmon 2007).

Cooptation of the clergy is reminiscent of past practices and shows how the clergy can be mobilized to convey the ideology proposed by leading political circles. It is through the control over their training, assignment and their speeches that the government can communicate preferred religious beliefs and orientations. Brill Olcott's (1994: 154) assessment that in Central Asia "the relationship between Islam and the state remains as tense as it was in Soviet days" still resonates today. There is, in continuation with Soviet practices, a great subordination of religious institutions to the authorities and state apparatus. Like in Soviet times, regulatory institutions are not only responsible for organizing relations between the community of believers and the State but also to promote a "traditional" and "legitimate" Islam as opposed to a radical, foreign Islam. Constitutional provisions assert the separation of state and religion in Tajikistan. Yet, state practices testify of a great involvement in religious affairs.

Continuity is also rhetorical in the sense that leaders carefully underline the threatening character of religion. Yet, whereas the Soviets tried to limit as much as possible the development of an Islamic identity, Tajik authorities are using the institutions to both circumscribe and steer the Muslim identity towards an Islam defined as national while using figures of the past (Olcott and Ziyaeva 2008, 22). Paradoxically, continuity also implies the persistence of problems such as the clergy's lack of legitimacy due to the great proximity with the state apparatus. The codification and criminalization of a number of private religious practices is also reminiscent of the Soviet period. And like in Soviet times, many unregistered places of worship and study continue to exist clandestinely.

\section{Conclusion}

Scholarly and public opinions tend to see the Soviet socio-political project as something spectacular and unique, in opposition to the historical development of secularization in the Western world. Such a view overemphasizes the totalitarian dimension of the Soviet regime neglecting the agency of sociopolitical actors (Yurchak 2003, 482). If the Soviet social engineering project was indeed incomparable, it is better understood as an accelerated modernization process rather than as an exceptional endeavour at odds with the development of the Western liberal societies. Still, in the Soviet case, state involvement in 
socialization and education was so overwhelming and coercive that it was successful in imposing certain behaviours and inhibiting others for several decades. But we cannot simply talk of the imposition and assimilation of social norms; it is rather the transformation and appropriation of these values that contribute to shape today's religious dynamics. I have argued that, rather than resignation and resistance, the concept of accommodation better reflects Soviet peoples' reaction to modernization and the resilience of Soviet values.

The reappropriation and internalization of values makes it difficult to distinguish between Soviet and post-Soviet orders and a great deal of authors contend that there is in fact no clear boundary between Soviet and post-Soviet periods (DeWeese 2002; Louw 2007; Peyrouse 2003; Rasanayagam 2011). Luehrmann's fascinating piece on religious education in rural Russia proposes to see the secular (Soviet) and post-secular periods not as eras opposed to each other but as "sites of engagement that alternate and overlap in the lives of both societies and individuals" $(2011,199)$. There is today a great continuity in the people understanding's of the place of religion in society, at both the political and social level. And in continuation with Soviet practices, religion continues to be greatly subordinated to the authorities and state apparatus.

Paradoxically, the religious revival taking place in Central Asia could also be interpreted in light of the Soviet legacy. In my own work (Thibault 2013), I suggested that Islamic values offset the Soviet holistic ideology, which can be explained by the affinities of religious and Soviet moral codes. Religion can be limiting as it imposes strict codes of conduct concerning social and personal behaviour in daily life. Yet, it matches a desire for social order in a difficult economic environment plagued by widespread corruption and lack of political openness. Just like the revolution in 1917 did not bring immediate socio-political changes, the sudden collapse of a whole ideological and political structure in 1991 did not result in the abrupt discard of the sociopolitical routine. The disintegration of the USSR surely created a destabilizing environment that allowed new forces to emerge but the Soviet legacies remain important in our understanding of prevailing socio-political patterns. 


\section{Bibliography}

Abdulgani, A. (1989). "Muslims in the conditions of glasnost, perestroika and new thoughts" (Musul'mane v uslovyax glastnosti, perestroika i novovo mishelnya). In Dimitri Efimovich Furman (ed.). Perestroika: Glastnost, Democracy, Socialism. On the Road to Freedom of Conscience (Perestroika: Glastnost, Democratiya, Socialism. Na puti k svobode sovesti). Moscow: Progress; 402-447.

Abdullaev, Z. (2005). "Tajikistan: Referendum Result Controversy". Institute of War and Peace Reporting. [http://iwpr.net/report-news/tajikistanreferendum-result-controversy] Accessed 20-06-2015.

Agadjanian, A. (2011). "Exploring Religiosity as a Source of Morality Today." In Jarrett Zigon (ed). Multiple Moralities and Religions in Post-Soviet Russia. New York: Berghahn Books; 16-26.

Adams, L. L. (1999). “The Mascot Researcher. Identity, Power, and Knowledge in Fieldwork." Journal of Contemporary Ethnography 28(4); 331-363.

Asia Plus. (2010). "Rakhmonov: Pust' vashix deteii uchat mully" (Rakhmonov: Send Your Children to Mullahs). September 17. [http:/ / news.tj/en/ node/1321] Accessed 20-06-2015.

Babajanov, B. (2000a). "Islam officiel contre Islam politique en Ouzbékistan aujourd'hui: la Direction des musulmans et les groupes non-hanafî." Revue d'études comparatives Est-Ouest 31(3): 151-164.

- (2000b). "Spiritual Muslim Board of Central Asia: Origin and Consequences of the Collapse" (Sredneazitaskoe Duxovnoe Upravlene Musul'man). In Martha Brill Olcott and Alexander Malashenko (eds). The Multidimensional Frontiers of Central Asia (Mnogomerne granitsy Tsentralnoii Azii). Moscow: Gendalf; 80-90.

BBC Monitoring Service. (2007). "Tajik leader voices concern about 'secret' Islamic schools". April 30. Source: Tajik Television First Channel, Dushanbe, in Tajik 0400 gmt April 302007.

Brill Olcott, M. 1994. “Central Asia's Islamic Awakening". Current History 93(582); 150-154.

- (2007). "Roots Of Radical Islam In Central Asia", Carnegie Papers. Carnegie Endowment For International Peace n.77. Washington and Moscow: Carnegie Endowment for International Peace.

Brill Olcott, M. and D. Ziyaeva. (2008). “Islam in Uzbekistan: Religious Education and State Ideology." Carnegie Papers. n.91. Washington and Moscow: Carnegie Endowment for International Peace.

Bryanov, V. A. (1986). The Atheistic Education of Students (Ateisticheskoe vospitane studentov). Moscow: High School Publications (Izdatelstvo Vyshaya Shkola). 
Cadiot, J. (2007). Le laboratoire impérial: Russie-URSS 1860-1940. Paris: CNRS

Carrère d'Encausse, H. (1978). L'Empire éclaté: la révolte des nations en URSS. Paris: Flammarion.

Codevilla, G. (1971). The Attitude of the Soviet State Towards Religion. Russia Cristiana: Milan.

Corley, F. (2009). “Tajikistan: President signs repressive Religion Law”. Forum 18. March 26.

[http:/ / www.forum18.org/Archive.php?article_id=1274] Accessed 1006-2013.

DeWeese, D. (2002). "Islam and the Legacy of Sovietology: A Review Essay on Yaacov Ro'i's Islam in the Soviet Union." Journal of Islamic Studies 13(3); 298-330.

Dudoignon, S. A. (2005). “From Ambivalence to Ambiguity? Some Paradigms of Policy Making in Tajikistan". In Luigi De Martino (ed). Tajikistan at a Crossroad: the Politics of Decentralisation. Cimera Situation reports; 120151.

Epkenhans, T. (2010). "Muslims without Learning, Clergy without Faith: Institutions of Islamic Learning in the Republic of Tajikistan." In Michael Kemper, Raoul Motika and Stefan Reichmuth (eds). Islamic Education in the Soviet Union and its Successor States. Edited by New York: Routledge; 313-348.

Fierman, W. (1991). Soviet Central Asia: The Failed Transformation. Boulder (CO): Westview Press.

Fourniau, V. (1994). Histoire de l'Asie centrale. Paris: PUF.

Fox, J. (2011). "Separation of Religion and State and Secularism in Theory and in Practice". Religion, State E Society 39(4); 384-401.

Gellner, E. (1991). "Islam and Marxism: Some Comparisons." International Affairs 67(1); 1-6.

- (2008). Nations and Nationalism. Ithaca (NY): Cornell University Press.

Haghayeghi, M. (1994). "Islamic Revival in the Central Asian Republics." Central Asian Survey 13(2), 249-266.

Husband, W. B. (2000). "Godless Communists" Atheism and Society in Soviet Russia 1917-1932. De Kalb (IL): Northern Illinois University Press.

International Crisis Group (ICG). (2003). "Central Asia: Islam and the State". ICG Asia Report. n.59.

[www.crisisgroup.org/en/regions / asia / central-asia/059-central-asiaislam-and-the-state.aspx] Accessed 20-06-2015.

Isazade, F. (2013). "Shafig Pshihachev: "Our goal - the consolidation of Muslims in the post-Soviet space"" (Shafig Pshikhachev: "Nasha tsel' konsolidatsiya musul'man na postsovetskom prostranstve"). Islam.az. April 29. [http: / / islam.az/news / a-13529.html] Accessed 20-06-2015. 
Islam News. (2015). "The building of the Islamic gymnasium given to the Pedagogical University residences" (Zdaniye Islamskoy gimnazii peredano pod obshchezhitiye Peduniversiteta). June 18. [http: / / islamnews.tj/ tajikistan/1161-zdanie-islamskoy-gimnaziiperedano-pod-obschezhitie-peduniversiteta.html] Accessed 20-06-2015.

Karagiannis, E. (2006). “The Challenge of Radical Islam in Tajikistan: Hizb utTahrir al-Islami". Nationalities Papers 34(1); 1-20.

- (2010). Political Islam in Central Asia: The challenge of Hizb ut-Tahrir. New York: Routledge.

Kenez, P. (1985). The Birth of the Propaganda State: Soviet Methods of Mass Mobilizations, 1917-1929. Cambridge: Cambridge University Press.

Keller, S. (2001). To Moscow Not Mecca: the Soviet Campaign Against Islam in Central Asia, 1917-1941. Westport (CT): Praeger Publishers.

Khamadov, S. and M. Olimov. (2003). "Informal Leaders in Central Asian Countries: Who will the new leaders be?" (Neformalnoe liderstvo v stranax Tsentralnoi Azii: kakimi budut novie vojdi). In Muzaffar Olimov and Saodat Olimova (eds). Muslim Leaders: Social Role and Legitimacy (Musul'manskie lideri: sotsialnaya rol i avtoritet). Dushanbe: Sharq Research Center; 47-53.

Kurochkin, P. K. (1983). "The Creative Role of the Scientific and Materialist Atheistic Weltanschauung in Moulding a New Type of Man" In S.C Dube and V.N Basilov (eds). Secularization in Multi-Religious Societies. Naurang Rai: New Delhi; 141-149.

Lane, C. (1984). "Legitimacy and Power in the Soviet Union through Socialist Ritual." British Journal of Political Science 14(2); 207-217.

Lenin, V. I. (1977). "The Three Sources and Three Component Parts of Marxism" [1913]. Lenin's Collected Works 19. Moscow: Progress Publishers; 21-28.

[http:/ / www.marxists.org/archive/lenin/works/1913/mar/x01.html] Accessed 10-06-2013.

Louw, M. E. (2007). Everyday Islam in Post-Soviet Central Asia. New York: Routledge.

Luehrmann, S. (2011). Secularism-Soviet Style. Teaching Atheism and Religion in a Volga Republic. Bloomington (IN): Indiana University Press.

Marsh, C. (2010). Religion and the State in Russia and China. Suppression, Survival, and Revival. London: Continuum.

Massell, G. J. (1974). The Surrogate Proletariat: Moslem Women and Revolutionary Strategies in Soviet Central Asia, 1919-1929. Princeton: Princeton University Press.

Mirsaidov, K., T. Rasul-Zoda and T. Dikaev. (2010). "Student's return - a political issue?" (Vozrashenie studentov - Vorpos politicheskii?) Asia Plus. 
[http: / / www.centrasia.ru/newsA.php?st=1291175400] Accessed 20-062015.

Myer, W. (2001). Islam and Colonialism: Western Perspectives on Central Asia. London: Routledge.

Najibulla, F. (2010). “Tajiks Stopped from Traveling to Iran, Pakistan for Religious Courses". Radio Free Europe News/Radio Liberty. September 08.

[http:/ / www.rferl.org/ content/Tajiks_Stopped_From_Traveling_to_Ir an_Pakistan_For_Religious_Courses/2152337.html] Accessed 20-062015.

Naumkin, V. (2005). Radical Islam in Central Asia: Between Pen and Rifle. Oxford: Rowman \& Littlefield.

Northrop, D. T. (2004). Veiled Empire: Gender and Power in Stalinist Central Asia. Ithaca (NY): Cornell University Press.

Olimova, S. (2000). "Islam and the Tajik Conflict." In Roald Sagdeev and Susan Eisenhower (eds). Islam and Central Asia: An Enduring Legacy or an Evolving Threat? Washington: Center for Political and Strategic Studies; 59-71.

Ozod, M. (2009). "Muhiddin Kabiri: too many limitations in the law on religion". (Muhiddin Kabiri: V novom zakone o religii slishkom mnogo ogranichenii). Ferghana News. March 16. [http: / / www.ferghana.ru/article.php?id=6097] Accessed 20-06-2015.

Peyrouse, S. (2003). Des chrétiens entre athéisme et islam: regards sur la question religieuse en Asie central soviétique et post-soviétique. Paris: Maisonneuve et Larose.

Poliakov, S. P. (1992). Everyday Islam: Religion and Tradition in Rural Central Asia. Armonk (NY): M.E. Sharpe.

Pospielovsky, D. V. (1987). A History of Marxist-Leninist Atheism and Soviet Antireligious policies. London: Macmillan Press.

Poujol, C. (2005). “Islam in Post-Soviet Central Asia: Democracy Versus Justice?" In Irina Morozova (ed.) Towards Social Stability and Democratic Governance in Central Eurasia. Amsterdam: IOS Press; 50-66.

Radio Free Europe/Radio Liberty. (2006). “Tajik President Creates OppositionFree Government". December 06.

—. (2011). "Tajiks Who Studied Abroad Face Criminal Charges". August 19. [http:/ / www.rferl.org/content/tajiks_who_studied_abroad_face_crimi nal_charges / 24301913.html] Accessed 20-06-2015.

—. 2013. "Five Of Six Legally-Run Tajik Madrasahs Suspended". July 12. [www.rferl.org/content/tajikistan-madrasahs-closed/25044410.html] Accessed 10-06-2015.

Rafiyeva, M. (2011). "Madrasah" operation ends up in northern Tajikistan". Asia Plus. June 17. [http://news.tj/en/news/madrasah-operationends-northern-tajikistan]. Accessed 20-06-2015. 
Rahmon, E. (2007). "Address of the President of the Republic of Tajikistan Emomali Rahmon at the Public Gathering on Regulating National Customs and Religious Rituals". May 24. [http:/ / www.prezident.tj/ rus/vistupleniy240507.htm] Broken link.

Rasanayagam, J. (2011). Islam in Post-Soviet Uzbekistan. The Morality of Experience. Cambridge: Cambridge University Press.

Rosenbaum, Y. A. (1985). The Soviet State and the Church (Sovetskoe gosudarstvo i tserkov). Moscow: Nauka.

Ro'i, Y. (2000). Islam in the Soviet Union. New York: Columbia University Press.

Roy, O. (2001). L'Asie centrale contemporaine. Paris: Presses Universitaires de France.

Rywkin, M. (1982). Moscow's Muslim Challenge: Soviet Central Asia. Armonk (NY): M.E. Sharpe.

Scott, J. C. (1985). Weapons of the Weak: Everyday Forms of Peasant Resistance. New Haven (CT): Yale University Press.

Skazkin, S. D. (ed). (1968). The Atheist's Handbook (Nastolnaya kniga ateista). Moscow: Izdatelstvo Politicheskoii Literatury (Political Literature Publishing).

Suny, R. G. (2012). “The Contradictions of Identity: Being Soviet and National in the USSR and after". In Mark Bassin and Catriona Kelly (eds). Soviet and Post-Soviet Identities. Cambridge: Cambridge University Press.

Thibault, H. (2013). "The Secular and the Religious in Tajikistan: Contested Political Spaces." Studies in Religion/Études religieuses 42(2): 173-189.

Todzhiddinov, A. (2011). "Where are the students who returned from Islamic countries?" (Kuda delis Studenty vernuvshiesya iz Islamkix stran) Asia Plus. September 29 [http://www.news.tj/ru/news/kuda-delisstudenty-vernuvshiesya-iz-islamskikh-stran] Accessed 20-06-2015.

Wanner, C. (2011). “Multiple Moralities, Multiple Secularisms." In Jarrett Zigon (ed). Multiple Moralities and Religions in Post-Soviet Russia. New York: Berghahn Books, p. 214-225.

Zigon, J. (ed). (2011). Multiple Moralities and Religions in Post-Soviet Russia. New York: Berghahn Books.

Yuldashev, A. (2011). “The Law on Parental Responsibility Came Into Force in Tajikistan" (V Tadzhikistane v silu vstupil zakon ob otvetstvennosti roditeleii). Asia Plus. August 06. [http://news.tj/ru/news/vtadzhikistane-v-silu-vstupil-zakon-ob-otvetstvennostiroditelei] Accessed 20-06-2015.

Yurchak, A. (2003). "Soviet Hegemony of Form: Everything Was Forever, until It Was No More". Comparative Studies in Society and History 45(3): 480510 . 